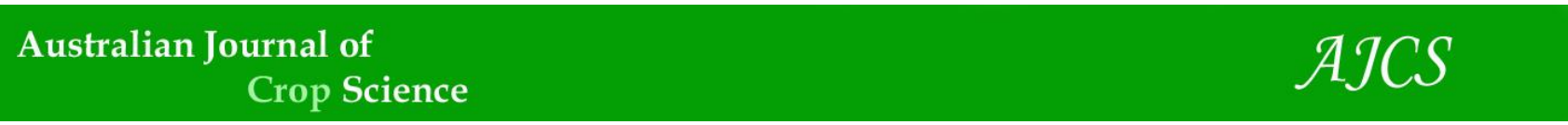

AJCS 15(03):445-454 (2021)

ISSN:1835-2707

doi: 10.21475/ajcs.21.15.03.p3061

\title{
Phytochemical content and antioxidant activity of Gynura procumbens in response to shade levels and rates of nitrogen fertilizer
}

\author{
Omar Ali Ahmed ${ }^{1,2}$, Martini Mohammad Yusoff ${ }^{1 *}$, Azizah Misran $^{1}$, and Puteri Edaroyati Megat Wahab ${ }^{1}$, \\ Hamid Zentou ${ }^{3}$ \\ ${ }^{1}$ Department of Crop Science, Faculty of Agriculture, Universiti Putra Malaysia, 43400 Serdang, Selangor, Malaysia \\ ${ }^{2}$ Department of Crop Science, Faculty of Agriculture, University of Diyala, Diyala, Iraq \\ ${ }^{3}$ Department of chemical and environmental engineering, Faculty of engineering, Universiti Putra Malaysia, 43400 \\ Serdang, Selangor, Malaysia
}

*Corresponding author: martinimy@upm.edu.my

\begin{abstract}
Gynura procumbens is one of the most common medicinal plants with extensive pharmacological properties. Light intensity and nitrogenous fertilisers are two main limiting factors in primary and secondary metabolism in plants. Information on the effects of shade levels and nitrogenous fertiliser rates on phytochemical content and antioxidant activity of G. procumbens is much scarce. This justifies an in-depth study to determine the effects of phytochemical content and antioxidant activity. This study was conducted with four levels of shade $(0,30,50$, and $70 \%)$ and four nitrogen fertilizer rates $\left(0,100,200\right.$ and $\left.300 \mathrm{~kg} \mathrm{~N} \mathrm{ha}^{-1}\right)$. Data measurements were performed on protein content, C: $\mathrm{N}$ ratio, total phenolic content (TPC), total flavonoid content (TFC), antioxidant activity (DPPH, FRAP) and flavonoid acids. The results showed that decreases in total phenol, flavonoid contents, C: $\mathrm{N}$ ratio and antioxidant activity were recorded with increasing shade levels and nitrogen rates. Protein content was increased with increases in shade levels and nitrogen fertilizer supplement. The highest flavonoid acids contents were observed from higher light intensity (no shade) and no nitrogen application. Enhancement in production of secondary metabolites and antioxidant activity were associated with high C:N ratio and low protein contents. The study demonstrated that high light intensity ( $0 \%$ shade) with a low $\mathrm{N}$ fertilizer rate $\left(0 \mathrm{~kg} \mathrm{~N}^{-1}\right)$ was suitable for both phenolic compounds and antioxidants activity. The present study suggested that $G$. procumbens can achieve higher production of polyphenolic compounds and antioxidant activity under low nitrogen availability and open field conditions.
\end{abstract}

Keywords: Gynura procumbens, shade, nitrogen, growth, phytochemical, antioxidant.

Abbreviations: C:N_carbon: nitrogen ratio; $C P$ _crude protein content; TPC_total phenolic content; TFC_total flavonoid content; DPPH_2, 2_Diphenyl_1_Picrylhydrazyl assay; FRAP_Ferric Reducing Antioxidant Power Assay; KMR_Kaempferol_3_rotinoside; KMG_Kaempferol_3_glucoside; MYR_Myricetin.

\section{Introduction}

Gynura procumbens is an annual evergreen medicinal herb belonging to the Asteraceae family. It is widely distributed in the African continent (Rahman and Al Asad, 2013; Sukadeetad et al., 2018) and tropical regions of South-east Asia including Malaysia, Indonesia, Thailand, Vietnam, Philippines and Myanmar, and China (Nasir et al., 2015; Mou and Dash, 2016; Tan et al., 2016). In Malaysia, the species is distributed mainly in the western part of the peninsula (Keng et al., 2009).

In countries like Malaysia, Indonesia and Vietnam, $G$. procumbens has been traditionally used in the treatments of various diseases and ailments such as rash, constipation, hypertension, migraines, diabetes mellitus, urinary infection, cancer and as an anti-inflammatory and anti-allergic agents (Perry and Metzger, 1980; Jiratchariyakul et al., 2000). The benefits of consuming $G$. procumbens are related to the presence of bioactive compounds such as saponins, flavonoids and terpenoids (Mou and Dash, 2016; Tan et al., 2016). Increase in knowledge of potential health benefits of the species as a medicinal plant, as an alternative to chemical remedies, has led to higher demand for the herb. Plant growth and production of metabolites depend on changes in the ecosystem. It has been documented that biotic and abiotic factors influence secondary metabolite production and they have a bearing on enhancing the potential to produce phytochemicals for use in various applications. Thakur et al. (2018) stated that the accumulation of secondary metabolites in plants would increase as plants respond to stress conditions. They emphasized that enhanced synthesis of secondary metabolites, called elicitation, ensures survival, persistence and competitiveness of the plant. Enhanced production of secondary metabolites has significant economic benefits for the pharmaceutical and therapeutic industries.

The concentration of polyphenols in plants has been reported to be influenced by environmental conditions (abiotic factors) such as light intensity, temperature and fertilization, and biotic factors, which alter the 
concentrations of the constituents (Fine et al., 2006). Irradiance is known to regulate not only plant growth and development, but also biosynthesis of both primary and secondary metabolites such as polyphenols (Hemm et al., 2004; Liu et al., 2002). Based on the effects of environmental conditions on carbon-nutrient balance, phenolic biosynthesis has been documented to require irradiance or is enhanced by irradiance (Zavala and Ravetta, 2001). Different plants have different responses to irradiance intensity that result in differences in their production of secondary metabolites depending on the species of plants. $\mathrm{Gu}$ et al. 2010 showed that differences in irradiance levels altered the production of secondary metabolites in plants. Consequently, the irradiance level affected the phytochemical content of these plants, besides changes in their morphology and physiology (Ferreira et al., 2007). These findings suggest that different irradiances have a direct effect on antioxidant activities in plants resulting in increased total phenolic and flavonoids contents (Ghasemzadeh et al., 2010; Nasiri, 2016).

In addition to sunlight, nitrogen is one of the main requisites for plant growth and is applied to crops in substantial amounts to ensure high yield. It strongly influences the use of other environmental resources such as water and light (Ibrahim et al., 2011). Nitrogen is generally accepted to be important in the biosynthesis of secondary metabolites which can also be altered by variations in environmental resources (Cai et al., 2009), and particularly plant nutritional status which could highly affect these metabolic compounds (El Gendy et al., 2015; Chrysargyris et al., 2016). Among the plant nutrients, nitrogen $(\mathrm{N})$ is much demanded than any other mineral elements and heavily influence the chemical compounds and biomass of plants (Barickman and Kopsell, 2016). Nitrogen has been considered a plant's essential mineral contributing to the biosynthesis of a wide range of compounds such as nucleic acids, enzyme, pigments polysaccharides, as well as some secondary metabolites (Kováčik and Klejdus, 2014; Chrysargyris et al., 2016). The availability of nitrogen affects the content of secondary components in several ways. Nitrogen availability can change $\mathrm{C}: \mathrm{N}$ balance in plants, as nitrogen deficiency promotes a shift from $\mathrm{N}$-based secondary to C-based secondary compounds (Ibrahim et al., 2011). Consequently, this suggests that all levels of plant function, from metabolism to resource allocation, growth, and development are regulated and coordinated with nitrogen availability. Therefore, the manipulations of nitrogen fertilizer rates can affect the production and concentration of primary and secondary metabolites. Therefore, a study was conducted to examine the effects of shade level and nitrogen fertilizer rate on total phenolic content, total flavonoid content, antioxidant activity and flavonoid acids of G. procumbens.

\section{Results}

\section{Carbon: nitrogen ratio (C:N)}

Shade levels and nitrogen fertilizer rate had significant effects on carbon: nitrogen ratio ( $\mathrm{C}: \mathrm{N})$ of $\mathrm{G}$. procumbens plants. It was seen that $\mathrm{C}: \mathrm{N}$ ratio increased with decrease in shade from $70 \%$ to full sunlight ( $0 \%$ of shade) and decreased with increase in nitrogen fertilizer rates from 0 to $300 \mathrm{~kg} \mathrm{~N}$ $\mathrm{ha}^{-1}$. Figures 1-A and 1-B show that under full sunlight and $70 \%$ shade level G. procumbens plants achieve a maximum C:N ratio of 16.36 and 11.91, respectively. However, lower nitrogen fertilizer rate $\left(0 \mathrm{~kg} \mathrm{~N} \mathrm{ha}^{-1}\right)$ also produced a high C:N ratio. The percentage increase was $76.39 \%$ in no nitrogen application $\left(0 \mathrm{~kg} \mathrm{~N} \mathrm{ha}^{-1}\right)$ than the higher nitrogen fertilizer rate of $300 \mathrm{~kg} \mathrm{~N} \mathrm{ha}^{-1}$ (Fig 1-B).

\section{Crude protein content (CP)}

Crud protein contents (CP) of Gynura procumbens in the present study were significantly affected by different levels of shade and nitrogen fertilizer rates. The plants showed high CP contents of 72.95 and $59.18 \%$ at 70 and 50\%, respectively when compared with $\mathrm{CP}$ content under full sunlight (Fig 2-A). Similarly, CP content increased with increase in nitrogen fertilizer supplementation. The increment in CP percentage was $62.79 \%$ when the plants were grown at $300 \mathrm{~kg} \mathrm{~N} \mathrm{ha}^{-1}$ compared to no nitrogen application (Fig 2-B).

\section{Total phenolic content (TPC)}

The total phenolic content of $G$. procumbens was markedly reduced in response to the increase in shade levels and nitrogen fertilizer rates (Fig 3). There were interaction effects between shade levels and nitrogen fertilizer rates. Mean TPC was $6.94 \mathrm{mg} \mathrm{GAE} / \mathrm{g}$ under open field ( $0 \%$ shade) and no nitrogen application $\left(0 \mathrm{~kg} \mathrm{~N} \mathrm{ha}{ }^{-1}\right)$, whereas the lowest TPC was 3.18, 3.05, 3.0 and $2.85 \mathrm{mg} \mathrm{GAE} / \mathrm{g}$ under the $70 \%$ shade and $0,100,200$ and $300 \mathrm{~kg} \mathrm{~N} \mathrm{ha}^{-1}$, without any significant difference with $3.02 \mathrm{mg} \mathrm{GAE} / \mathrm{g}$ under $50 \%$ shade and $300 \mathrm{~kg} \mathrm{~N} \mathrm{ha}^{-1}$ (Figure 3).

Table 1 shows that there was no significant interaction $(p>0.05)$ between shade levels and nitrogen fertilizer rate in TPC of stem and root. However, the effects of both shade levels and nitrogen rates on stem and root TPC were significant. The maximum stem and root TPC were 2.29 and $1.99 \mathrm{mg} \mathrm{GAE} / \mathrm{g}$ observed under open field ( $0 \%$ shade), and the minimum were 1.54 and $1.14 \mathrm{mg} \mathrm{GAE} / \mathrm{g}$ under $70 \%$ shade. The maximum stem and root TPC under nitrogen fertiliser rates were 2.18 and $1.78 \mathrm{mg} \mathrm{GAE} / \mathrm{g}$, respectively, which observed under $0 \mathrm{~kg} \mathrm{~N} \mathrm{ha}^{-1}$ of nitrogen rate and the minimum were 1.49 and $1.22 \mathrm{mg} \mathrm{GAE} / \mathrm{g}$ under $300 \mathrm{~kg} \mathrm{~N}^{-1}$ of nitrogen.

\section{Total flavonoid content (TFC)}

There was a significant interaction effect between shade levels and nitrogen fertilizer rates on TFC concentration. Total flavonoid content (TFC) of G. procumbens was markedly reduced in response to an increase in nitrogen fertilizer rate (Fig 4). The average total of TFC produced was $5.29 \mathrm{mg} \mathrm{CE} / \mathrm{g}$ under $0 \%$ shade and no nitrogen application (0 $\mathrm{kg} \mathrm{N} \mathrm{ha}{ }^{-1}$ ). The lowest TFC was 2.62, 2.51 and $2.32 \mathrm{mg} \mathrm{CE} / \mathrm{g}$ at 100,200 and 300$) \mathrm{kg} \mathrm{N} \mathrm{ha}^{-1}$, respectively, under $70 \%$ shade, without any significant difference with 2.81 and 2.69 $\mathrm{mg} \mathrm{CE} / \mathrm{g}$ for 200 and $300 \mathrm{~kg} \mathrm{~N} \mathrm{ha}^{-1}$ under $50 \%$ shade.

Table 2 shows that there was no significant interaction $(P>0.05)$ between shade and nitrogen rates in stem and root TFC. However, the effect of both shade levels and nitrogen rates on the stem and root TFC was significant. The maximum stem and root TFC were 1.80 and $1.59 \mathrm{mg} \mathrm{CE} / \mathrm{g}$ which observed under $0 \%$ shade. The minimums were 1.26 and $1.42 \mathrm{mg} \mathrm{CE} / \mathrm{g}$ under 70 and $50 \%$ shade for stem and 0.97 and $0.90 \mathrm{mg} \mathrm{CE} / \mathrm{g}$ under 50 and $70 \%$ shade for roots, respectively. The maximum stem and root TFC under nitrogen fertiliser rate was 1.84 and $1.43 \mathrm{mg} \mathrm{CE} / \mathrm{g}$ which observed under no nitrogen application $\left(0 \mathrm{~kg} \mathrm{~N} \mathrm{ha}^{-1}\right)$ and the minimum were 1.19 and $0.91 \mathrm{mg} \mathrm{CE} / \mathrm{g}$ under $300 \mathrm{~kg} \mathrm{~N} \mathrm{ha}^{-1}$ of nitrogen, respectively. 
Effect of shade levels and fertilizer rate on antioxidant activities

\section{2, 2-Diphenyl-1-Picrylhydrazyl (DPPH) assay}

Increasing shade levels and nitrogen fertilizer rates had significant effects on the 2, 2-Diphenyl-1-picrylhydrazyl (DPPH) assay of $G$. procumbens plants $(P \leq 0.05)$. Figure 5-A shows that shade effects were more visible on DPPH assay at 80.36 and $78.71 \%$, when plants were grown under 0 and $30 \%$ shade levels. However, the lowest was $69.20 \%$ under $70 \%$ shade. On the other hand, no nitrogen application $(0 \mathrm{~kg}$ $\mathrm{ha}^{-1}$ ) resulted in higher percentage of DPPH inhibition $78.83 \%$ than 74.13 and $73.20 \%$ under 200 and $300 \mathrm{~kg} \mathrm{~N} \mathrm{ha}^{-1}$ of nitrogen rate, respectively (Figure 5-B).

\section{Ferric Reducing Antioxidant Power (FRAP) assay}

Shade levels and nitrogen fertilizer rates had significant effects on ferric reducing antioxidant power (FRAP), $(P \leq 0.05)$. The percentage of inhibition of FRAP was decreased by $25.91 \%$ with increases in shade levels from 0 to $70 \%$ shade (Figure 6- A). Low nitrogen rates of 0 and 100 $\mathrm{kg} \mathrm{ha}{ }^{-1}$ recorded higher inhibition of FRAP of 74.47 and 72.21 , in comparison with 69.61 and 67.35 at 200 and $300 \mathrm{~kg}$ $\mathrm{N} \mathrm{ha}{ }^{-1}$ of nitrogen supplementation (Fig 6- B).

\section{Effect of shade levels and fertilizer rate on flavonoid compounds}

\section{Kaempferol-3- rotinoside (KMR)}

There was a significant interaction effect between shade levels and nitrogen fertilizer rates on Kaempferol-3rotinoside (KMR). Results showed that KMR considerably decreased with increase in shade levels and nitrogen fertilizer rates. No nitrogen application $\left(0 \mathrm{~kg} \mathrm{~N} \mathrm{ha}{ }^{-1}\right)$ produced higher KMR $(0.96 \mathrm{mg} / \mathrm{g})$ under full sunlight without any difference with KMR $(0.90 \mathrm{mg} / \mathrm{g})$ at $100 \mathrm{~kg} \mathrm{~N} \mathrm{ha}$ ${ }^{1}$ under the same shade level. On the other hand, the lowest $\mathrm{KMR}$ was recorded at $0.079,0.054$ and $0.030 \mathrm{mg} / \mathrm{g}$ at 300 , 200 and $100 \mathrm{~kg} \mathrm{~N} \mathrm{ha}^{-1}$ of nitrogen supplementation under $70 \%$ shade (Fig 7).

\section{Kaempferol-3- glucoside (KMG)}

The kaempferol-3- glucoside (KMG) of Gynura procumbens plants was affected by the interaction effect of shade levels and nitrogen fertilizer rates. KMG decreased consistently with the increase in both shade levels and nitrogen fertilizer rates. The results indicated high KMG of $1.80 \mathrm{mg} / \mathrm{g}$ at no nitrogen application ( $0 \mathrm{~kg} \mathrm{~N} \mathrm{ha}{ }^{-1}$ ) under full sunlight, whereas the lowest value of KMG was $0.19,0.17$ and 0.13 $\mathrm{mg} / \mathrm{g}$ at 100,200 and $300 \mathrm{~kg} \mathrm{~N}^{-1}$ of nitrogen fertilizer, respectively, under $70 \%$ shade without any difference with $0.27 \mathrm{mg} / \mathrm{g}$ at $300 \mathrm{~kg} \mathrm{~N}^{-1}$ under $50 \%$ shade (Fig 8).

\section{Myricetin (MYR)}

Significant interaction $(P \leq 0.05)$ was observed between shade levels and nitrogen fertilizer rates in myricetin (MYR) of Gynura procumbens plants. Results showed that MYR considerably decreased with increases in both shade levels and nitrogen rates. The shade of $0 \%$ yielded higher MYR at 0.26 and $0.25 \mathrm{mg} / \mathrm{g}$ when plants were supplemented with 0 and $100 \mathrm{~kg} \mathrm{~N} \mathrm{ha}^{-1}$ of nitrogen fertilizer, respectively. On the other hand, the lowest MYR of 0.014 and $0.014 \mathrm{mg} / \mathrm{g}$ were recorded at 300 and $200 \mathrm{~kg} \mathrm{~N} \mathrm{ha}^{-1}$ of nitrogen fertilizer supplementation under $70 \%$ shade, respectively (Fig. 9).

\section{Discussion}

Metabolism of primary and secondary metabolites in plants is known to be influenced by environmental conditions which alter the contents of these active constituents (Ibrahim et al., 2011). In Table 1, C:N ratio of G. procumbens was decreased to $27.26 \%$ and $43.3 \%$ when shade level was increased from 0 to $70 \%$ and nitrogen rate was increased from 0 to $300 \mathrm{~kg} \mathrm{~N} \mathrm{ha}^{-1}$, respectively. The increase in C:N ratio under high light intensity with low nitrogen supply was probably due to reduced nitrogen uptake which resulted in increased C: $\mathrm{N}$ ratio. The results were in agreement with studies of (Cronin and Lodge, 2003; Ibrahim and Jaafar, 2012; Oskoee et al., 2018). According to C:N balance hypothesis, when nitrogen is readily available, plants primarily make compounds with high nitrogen content (e.g., proteins for growth). However, when nitrogen availability is limited, metabolism changes more towards carboncontaining compounds such as starch, cellulose, and non-Ncontaining secondary metabolites such as phenolics and terpenoids (Gu et al., 2010). Rahmat et al. (2008) documented that plants allocate extra carbon that could not be used for growth to produce carbon based secondary metabolites. Conversely, crude protein content was increased $73 \%$ when the shade level increased from 0 to $70 \%$, and $62.94 \%$ when nitrogen rate increased from 0 to $300 \mathrm{~kg} \mathrm{~N} \mathrm{ha}{ }^{-1}$. The differences in protein content in plants under different light intensity are related to the effect of light intensity on leaf nitrogen content. Under high light irradiance, leaf nitrogen content reduces. However, at low light conditions, leaf nitrogen content is increased as a physiological response to increase light absorption by increasing chlorophyll content. A higher nitrogen content under low light may be associated with elevated levels of protein detected in plants under shade (Nasiri 2016). Nitrogen is a major structural component of protein. Therefore, increase in nitrogen rate can result in increase in protein concentration (Robredo et al., 2011; Nasiri, 2016). The soluble protein content may increase with increasing nitrogen fertilization levels from 0 to $270 \mathrm{~kg} \mathrm{~N} \mathrm{ha}^{-1}$ (Ibrahim et al., 2013).

As shown in Figure 3, TPC was decreased $58.99 \%$ when compared with combined treatments of $0 \%$ shade and $0 \mathrm{~kg}$ $\mathrm{N} \mathrm{ha}^{-1}$ ) and $70 \%$ shade and $300 \mathrm{~kg} \mathrm{~N} \mathrm{ha}^{-1}$. Similarly, TFC was decreased to $56.14 \%$ under the same treatments of TPC (Fig 4). The reduced TPC and TFC with increasing shade level and nitrogen rate were related to the negative effect of these factors on plant defense compounds.

Light is one of the most extensively studied environmental factors in phenolic metabolism in plants (Macheix et al., 1990). Phenol and flavonoid biosyntheses require light or are enhanced by light. Flavonoid formation is absolutely light-dependent, and its biosynthetic rate is related to light intensity and density (Ghasemzadeh et al., 2010). Bussotti (2008) noted that ability of plants to produce defense compounds make them highly resilient to environmental stress. In the present study, there was a significant positive correlation between TPC and TFC with C:N ratio $(r=0.66$ and 0.66 ) respectively (Table 2 ). The carbon/nitrogen balance hypothesis states that when nitrogen availability is limited in the soil, plant growth also limits the rate of photosynthesis, which results in allocation of the extra carbon that cannot be used for growth on the production of carbon- based secondary metabolites. Ibrahim et al. (2011) reported that the increase in production of TPC and TFC under low 
Table 1. Effect of shade levels and nitrogen fertilizer rates on total phenol and total flavonoid content of stem and root of Gynura procumbens.

\begin{tabular}{|c|c|c|c|c|}
\hline \multirow[t]{2}{*}{ Treatment } & \multicolumn{2}{|c|}{ TPC } & \multicolumn{2}{|c|}{ TFC } \\
\hline & Stem & Root & Stem & Root \\
\hline \multicolumn{5}{|l|}{ Shade (S)\% } \\
\hline 0 & $2.29^{\mathrm{a}}$ & $1.99^{\mathrm{a}}$ & $1.80^{\mathrm{a}}$ & $1.59^{\mathrm{a}}$ \\
\hline 30 & $1.92^{b}$ & $1.56^{b}$ & $1.58^{b}$ & $1.18^{b}$ \\
\hline 50 & $1.68^{\mathrm{bc}}$ & $1.25^{b c}$ & $1.42^{b c}$ & $0.97^{c}$ \\
\hline 70 & $1.54^{c}$ & $1.14^{c}$ & $1.26^{\mathrm{c}}$ & $0.90^{c}$ \\
\hline LSD & 0.264 & 0.389 & 0.166 & 0.080 \\
\hline \multicolumn{5}{|c|}{ Nitrogen (N) (kg N ha ${ }^{-1}$ ) } \\
\hline 0 & $2.18^{a}$ & $1.78^{a}$ & $1.84^{\mathrm{a}}$ & $1.43^{\mathrm{a}}$ \\
\hline 100 & $2.03^{a}$ & $1.54^{b}$ & $1.63^{b}$ & $1.23^{b}$ \\
\hline 200 & $1.73^{b}$ & $1.40^{b}$ & $1.40^{\mathrm{C}}$ & $1.06^{c}$ \\
\hline 300 & $1.49^{c}$ & $1.22^{c}$ & $1.19^{d}$ & $0.91^{d}$ \\
\hline LSD & 0.194 & 0.147 & 0.114 & 0.090 \\
\hline SxN & ns & ns & ns & ns \\
\hline
\end{tabular}
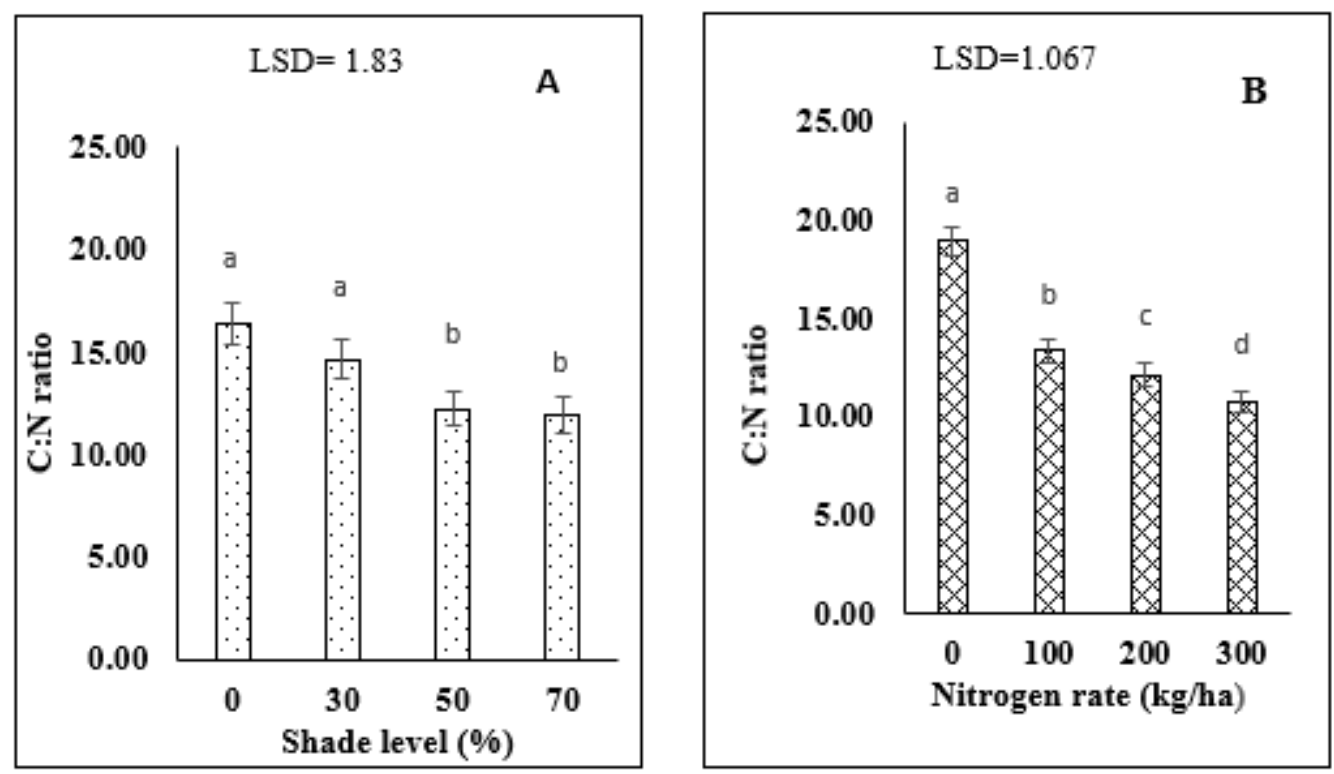

Fig 1. Effects of shade levels (A) and nitrogen fertilizer rates (B) on G. procumbens carbon: nitrogen ratio (C: N).

Table 2: Correlation coefficient $(r)$ between carbon- nitrogen ratio $(C ; N)$, crude protein $(C P)$, total phenolic content (TPC), total flavonoid content (TFC) , 2, 2-Diphenyl-1-picrylhydrazyl assay (DPPH), Ferric Reducing Antioxidant Power assay (FRAP), Kaempferol-3- rotinoside (KMR), Kaempferol-3- glucoside (KMG) and myricetin (MYR) of G. procumbens under different shade levels and nitrogen fertilizer rates.

\begin{tabular}{|c|c|c|c|c|c|c|c|c|c|}
\hline & $\mathrm{C}: \mathrm{N}$ & $\mathrm{CP}$ & TPC & TFC & DPPH & FRAP & KMR & KMG & MYR \\
\hline \multirow[t]{2}{*}{$\mathrm{C}: \mathrm{N}$} & - & -0.69 & 0.66 & 0.66 & 0.63 & 0.62 & 0.63 & 0.69 & 0.67 \\
\hline & & $* * *$ & $* * *$ & $* * *$ & $* * *$ & $* * *$ & $* * *$ & $* * *$ & $* * *$ \\
\hline \multirow[t]{2}{*}{$\mathrm{CP}$} & & - & -0.67 & -0.75 & -0.73 & -0.76 & -0.75 & -0.77 & -0.81 \\
\hline & & & $* * *$ & $* * *$ & $* * *$ & $* * *$ & $* * *$ & $* * *$ & $* * *$ \\
\hline \multirow[t]{2}{*}{ TPC } & & & - & 0.88 & 0.76 & 0.89 & 0.91 & 0.92 & 0.85 \\
\hline & & & & $* * *$ & $* * *$ & $* * *$ & $* * *$ & $* * *$ & $* * *$ \\
\hline \multirow[t]{2}{*}{ TFC } & & & & - & 0.75 & 0.83 & 0.86 & 0.87 & 0.84 \\
\hline & & & & & $* * *$ & $* * *$ & $* * *$ & $* * *$ & $* * *$ \\
\hline \multirow[t]{2}{*}{ DPPH } & & & & & - & 0.83 & 0.82 & 0.82 & 0.85 \\
\hline & & & & & & $* * *$ & $* * *$ & $* * *$ & $* * *$ \\
\hline \multirow[t]{2}{*}{ FRAP } & & & & & & - & 0.91 & 0.90 & 0.91 \\
\hline & & & & & & & $* * *$ & $* * *$ & $* * *$ \\
\hline \multirow[t]{2}{*}{ KMR } & & & & & & & - & 0.97 & 0.90 \\
\hline & & & & & & & & $* * *$ & $* * *$ \\
\hline \multirow[t]{2}{*}{ KMG } & & & & & & & & - & 0.91 \\
\hline & & & & & & & & & $* * *$ \\
\hline MYR & & & & & & & & & - \\
\hline
\end{tabular}



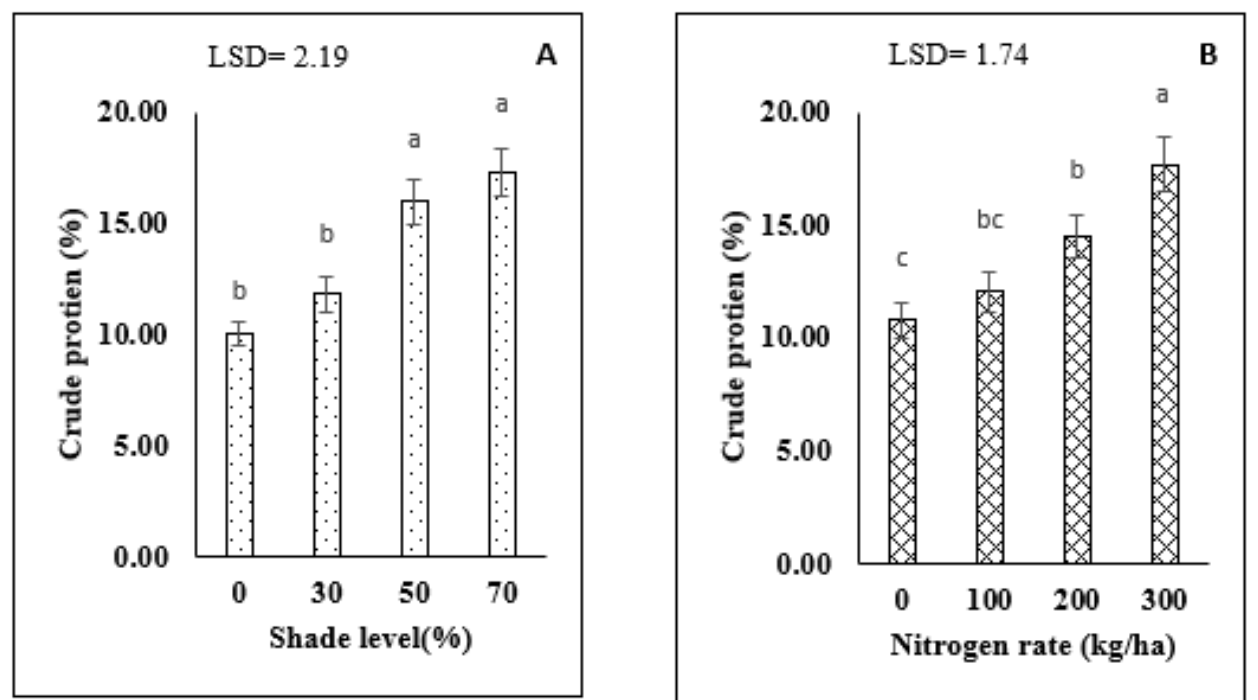

Fig 2. Effects of shade levels (A) and nitrogen fertilizer rates (B) on G. procumbens crude protein contents (\%).

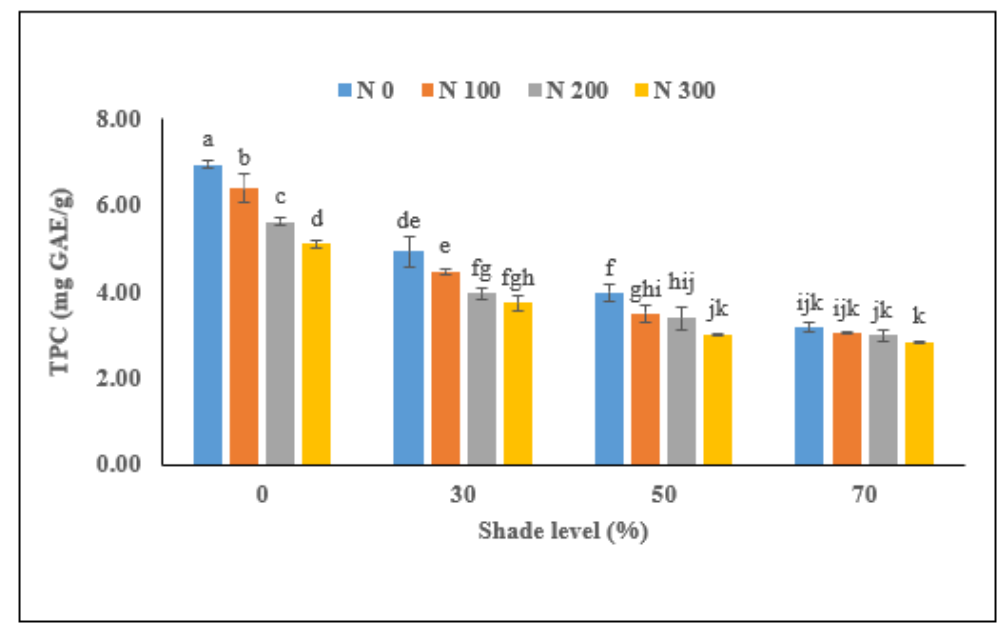

Fig 3. Effect of shade levels and nitrogen fertilizer rates on total phenolic content (TPC) (mg GAE/g) of Gynura procumbens.

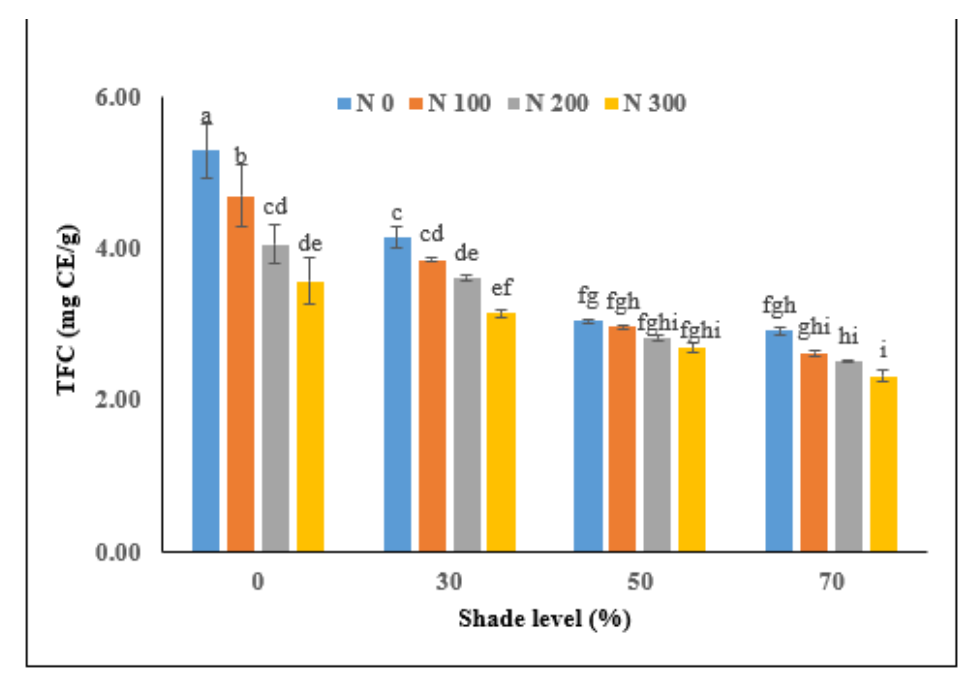

Fig 4. Effects of shade levels and nitrogen fertilizer rates on total flavonoid content (TFC mg $\mathrm{CE} / \mathrm{g}$ ) of G. procumbens. 

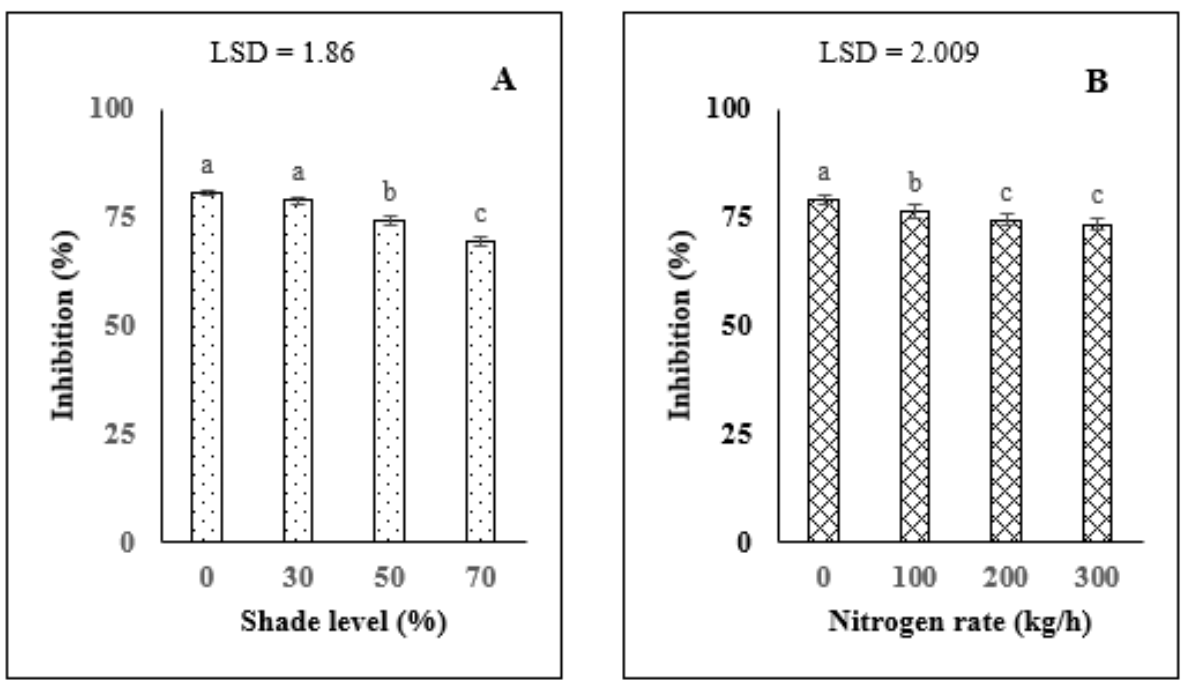

Fig 5. Effects of shade levels (A) and nitrogen fertilizer rates (B) on G. procumbens DPPH activity.
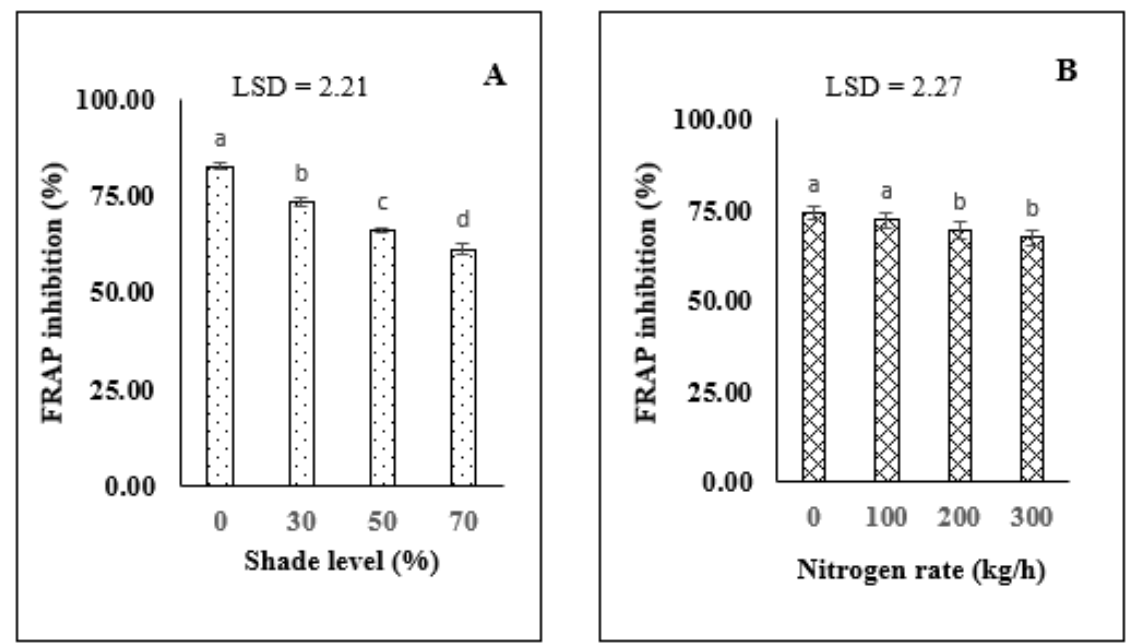

Fig 6. Effect of shade levels (A) and nitrogen fertilizer rates (B) on G. procumbens FRAP activity.

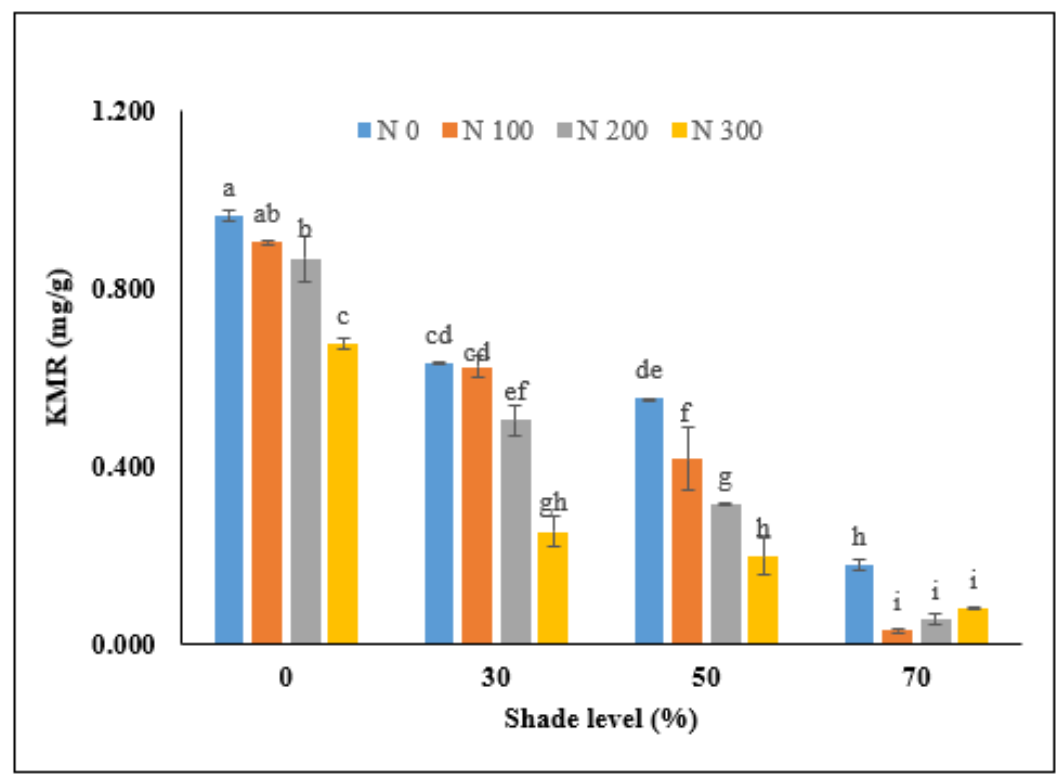

Fig 7. Effects of shade levels and nitrogen fertilizer rates on total Kaempferol-3- rutinoside content (KMR mg /g) of G. procumbens. 


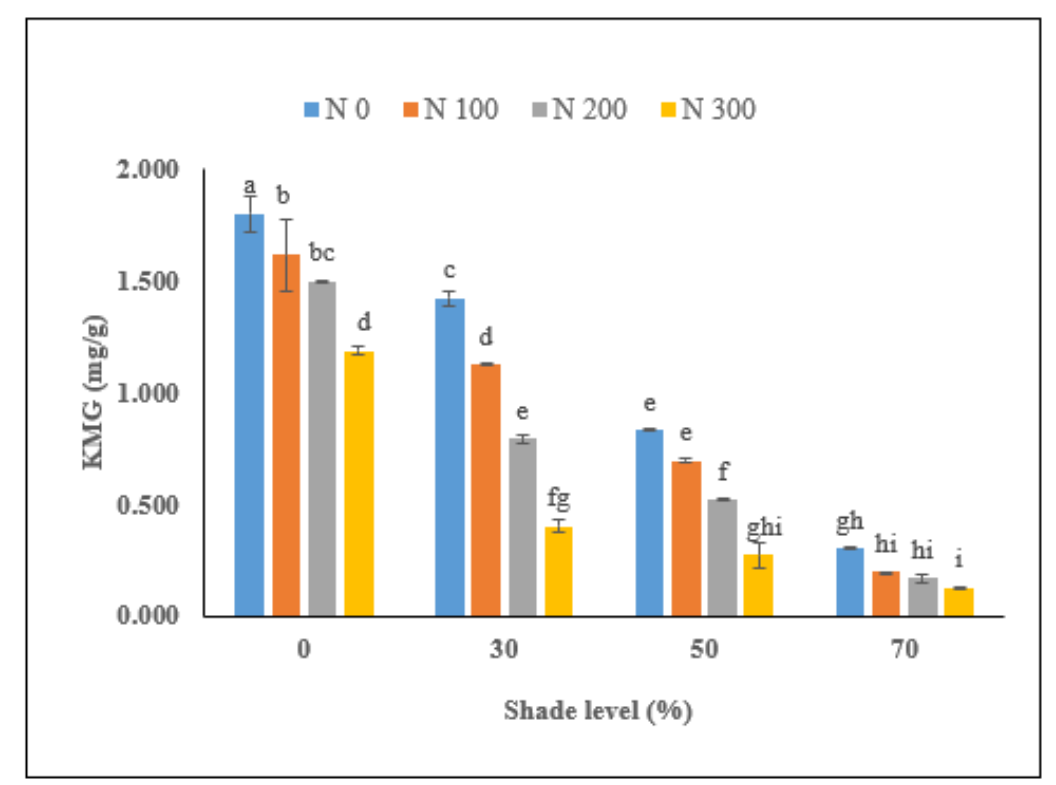

Fig 8. Effects of shade levels and nitrogen fertilizer rates on Kaempferol-3- glucoside content (KMG mg /g) of G. procumbens.

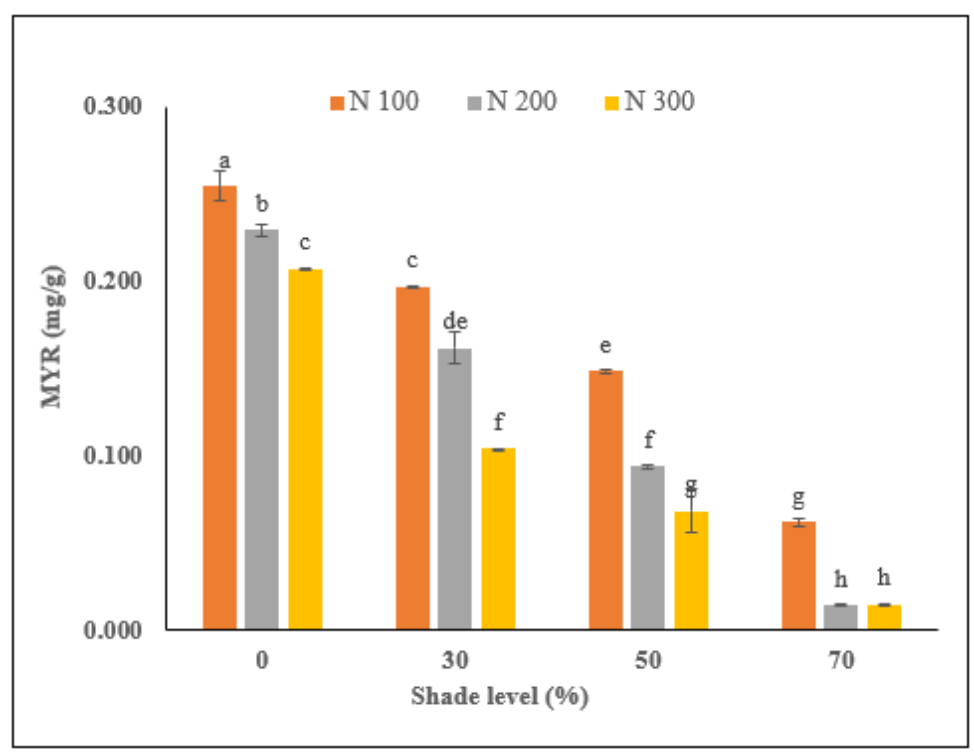

Fig 9. Effects of shade levels and nitrogen fertilizer rates on myrecetin content (MYR $\mathrm{mg} / \mathrm{g}$ ) of G. procumbens

The enhancement in PAL activity was followed by a reduction in the production of soluble protein under low nitrogen fertilization indicating more availability of amino acid phenylalanine (phe) under low nitrogen content that stimulates the production of carbon based secondary metabolites. The latter was manifested by high C: $\mathrm{N}$ ratio in L. pumila plants (Ibrahim et al., 2011).

Phenylalanine is a precursor of flavonoids and phenolics synthesis. It is assumed that biosynthesis of polyphenolic compounds may compete with protein synthesis for phenylalanine and that secondary metabolites synthesis may be inhibited because of limiting availability under conditions of rapid incorporation into protein.

The enhancement in secondary metabolites and antioxidant activity was associated with high C: $\mathrm{N}$ ratio and low protein contents (Oskoee et al., 2018). The inverse relationship between protein content and both TPC and TFC showed that there was a significant negative correlation between crude protein and TPC and TFC ( $r=-0.67$ and -0.75 , respectively, Table 2). The high content of flavonoid, phenols and antioxidant was characteristic for non-fertilized plants. Increase in the secondary metabolites at low nitrogen levels could be due to the increase in the nonstructural carbohydrates and enzymatic activity (Ibrahim et al., 2011). Similar to other medicinal plants, there was strong positive correlation between (TPC and TFC) with antioxidant activity (DPPH and FRAP) ( $r=0.76$ and 0.89 ) for TPC and $(r=0.75$ and 0.83 ) for TFC respectively, in $G$. procumbens plant. This finding is in agreement with (Podsędek, 2007; Can et al., 2017) which elucidated that phenol and flavonoid contents directly affect antioxidant capacity. The high light intensity with low nitrogen rates increases total phenol, flavonoid and antioxidant activity of $G$. procumbens. It is well-known that different biotic and abiotic stresses cause variations in antioxidant activity (Bessada et al., 2016), as found in the present study where excessive light intensity with nitrogen 
deficiency stress were accompanied by the higher antioxidant activity of the plants. Similar trends were observed that plant responded to different stresses by improving antioxidant activity (Zhao et al., 2016).

Kaempferol myrecetin are the rare flavonoid components in plants and they are the dominant flavonoids present in the G. procumbens extraction (Kim et al., 2011) showing significantly strong correlation between TFC and flavonoid acids (KMR, KMG and MYR) ( $r=0.86,0.87$ and 0.84) respectively (Table 2 ). The highest content of flavonoid acids (Keampferol-3-glocuside, Keampferol-3-rutinoside and myrecetin) were at $0 \%$ shade under no nitrogen application $\left(0 \mathrm{~kg} \mathrm{~N} \mathrm{ha}^{-1}\right)$ due to the excessive radiation and nitrogen deficiency as a stress condition.

\section{Materials and methods}

\section{Plant propagation}

A total of $300 \mathrm{G}$. procumbens cuttings were initially propagated in Field 2, Faculty of Agriculture, Universiti Putra Malaysia (UPM), Serdang, Selangor. In order to reach the adequate number of homogenous seedlings twice the number of cuttings required for the experiment were multiplied to produce 1400 cuttings later to be used for the subsequent experiments in Field 15, Faculty of Agriculture, UPM. The cuttings were initially grown for three weeks in small paper cups which were later transferred to polybags filled with a thoroughly sieved mixture of topsoil, sand and peat moss in a ratio of 3:1:2 (v/v).

\section{Experimental Design and Treatments}

The experiment was based on Nested Design with four replicates. The treatments included four shade levels $(0,30$, 50 and $70 \%$ ) by using shading net (the average daily light intensity were $1375,923,527$ and $312 \mu \mathrm{mol} / \mathrm{m}^{2} / \mathrm{s}$ under the open field, 30,50 and $70 \%$ shade respectively) with four nitrogen fertilizer rates $\left(0,100,200\right.$ and $\left.300 \mathrm{~kg} \mathrm{~N} \mathrm{ha}^{-1}\right)$. The polybags with the plants were allotted randomly to the treatments by Randomized Complete Block Design (RCBD). Each treatment consisted of 15 plants, giving a total number of plants of 960 . Plants were harvested at 12 weeks after transplanting.

\section{Study Parameters}

The present study involved the measurement of the following parameters to assess the effects of shade levels and nitrogen fertilizer rates:

\section{Crude protein content and $\mathrm{C}: \mathrm{N}$ ratio}

Total carbon and nitrogen were measured to determine $\mathrm{C}: \mathrm{N}$ ratio by using a CNS 2000 analyzer (Model A Analyst 300, LECO Inc., USA) according to Ibrahim et al. (2011). This was performed by placing $0.05 \mathrm{~g}$ of ground leaf samples in combustion boats. Successively, the combustion boats were transferred to a loader before the samples were burned at $1350{ }^{\circ} \mathrm{C}$ to obtain the reading of total carbon and nitrogen content of the samples. The $\mathrm{C}: \mathrm{N}$ ratio was determined by divided carbon content to nitrogen content. The crude protein concentration was determined by multiplying nitrogen concentration with a constant 6.25.

\section{Phytochemical Constituents}

\section{Extraction}

Dry samples were extracted from G. procumbens following procedures of (Kaewseejan and Siriamornpun 2015) with some modifications. The dried ground samples of $G$. procumbens were extracted three times with $95 \%$ ethanol under constant stirring for $3 \mathrm{~h}$ at room temperature. The extract was then filtered using a sterilized cotton filter and Whatman No.1 filter papers. The solvent was completely removed by a rotary evaporator at $35^{\circ} \mathrm{C}$ in a vacuum and the crude ethanoic extract (CEE) was obtained. An amount of $1 \mathrm{mg}$ CEE was taken from each sample and dissolved in $1 \mathrm{ml}$ ethanol and kept in $\mathrm{a}-80^{\circ} \mathrm{C}$ deep freezer.

\section{Total Phenolic Content}

The quantification of total phenolics content (TPC) from $G$. procumbens samples extracts was performed using FolinCiocalteu reagent method (Kaewseejan and Siriamornpun 2015). An amount of $200 \mu \mathrm{l}$ of each extract was pipetted into test tubes and $1 \mathrm{ml}(10 \% \mathrm{v} / \mathrm{v})$ of Folin-Ciocalteu reagent added into each extract sample. Five minutes after incubation, $800 \mu \mathrm{l}$ of $7.5 \%(\mathrm{w} / \mathrm{v})$ sodium carbonate solution were added into the samples. The samples mixture was incubated for 30 minutes at room temperature. The absorbance of the solution was reached at $765 \mathrm{~nm}$ by a spectrophotometer. TPC was reported as $\mathrm{mg}$ Gallic acid equivalents per gram dry weight (mg GAE/g DW).

\section{Total Flavonoid Content}

Total flavonoid content (TFC) of G. procumbens leaf extracts was determined using aluminium chloride colourimetric method adapted from the procedures reported by (Kaewseejan and Siriamornpun, 2015). An amount of $250 \mu \mathrm{l}$ of leaf extract solution was mixed with $1.25 \mathrm{ml}$ distilled water and $75 \mu$ lof sodium nitrite (NaNO2) solution. After 6 minutes of incubation, $150 \mu \mathrm{l}$ of $10 \%$ aluminium chloride solution $(\mathrm{AlCl} 3)$ was added into the mixture solution. The mixture was allowed to stand for another five minutes before adding $500 \mu \mathrm{l}$ of $1 \mathrm{M}$ sodium hydroxide $(\mathrm{NaOH})$. Distilled water was added into the mixture solution to make up to a total volume of $2.5 \mathrm{ml}$. The absorbance was measured at $510 \mathrm{~nm}$ using UV-Visible spectrophotometer. TFC was expressed as $\mathrm{mg}$ catechin equivalent per gram dry weight (mg CE/g DW).

\section{Antioxidant Activities}

\section{2, 2-Diphenyl-1-picrylhydrazyl (DPPH) Assay}

The antioxidant activity of the ethanol extract was determined using 1, 1-diphenyl-2-picrylhydrazyl (DPPH) radical base on the electron transfer reaction between DPPH reagent and the plant extracts. A $40 \mu \mathrm{L}$ of plant extract was added to $195 \mu \mathrm{L}$ of $0.1 \mathrm{mM}$ ethanolic DPPH solution following the method described by (Wong et al., 2006) with some modification. The mixture then was incubated in room temperature for $30 \mathrm{~min}$ under dark conditions before measuring at $515 \mathrm{~nm}$ using a spectrophotometer. The per cent of inhibition was calculated using the following formula:

Percent inhibition (\%) $=[(\mathrm{A} 515$ of control $-\mathrm{A} 515$ of sample)/A515 of control] $\times 100$.

\section{Ferric Reducing Antioxidant Power (FRAP) Assay}

The FRAP assay was conducted using the method of (Wong et al., 2006). Two hundred microliter of extract were added to $3 \mathrm{ml}$ of FRAP reagent that was prepared with a mixture of $300 \mathrm{mM}$ sodium acetate buffer at $\mathrm{pH}$ 3.6, $10 \mathrm{mM} \mathrm{2,} \mathrm{4,} \mathrm{6-tri}$ 
(2-pyridyl)-s-triazine (TPTZ) solution and $20 \mathrm{mM} \mathrm{FeCl.6H2O}$ at the ratio of $10: 1: 1$. The reaction mixture was incubated in a water bath at $37^{\circ} \mathrm{C}$ for $30 \mathrm{~min}$. The increase in absorbance was measured using a spectrophotometer at $593 \mathrm{~nm}$. The antioxidant capacity based on the ability to reduce ferric ions of the extracts was calculated as a percent of antioxidant. The percent of antioxidant was calculated using the following formula:

Percent antioxidant $(\%)=[(\mathrm{A} 593$ of sample-A593 of control)/A593 of sample] x 100 .

\section{Flavonoid compounds (Kaempferol and Myricetin)}

Kaempferol and Myricetin constituents were estimated using RP-HPLC (LC-20AC, Shimadzu, Japan), following the procedure reported by (Butsat, Weerapreeyakul, and Siriamornpun 2009). Extracted samples were dissolved in ethanol, followed by filtration through a $0.45 \mu \mathrm{m}$ membrane filter, and a volume of dissolved from $20 \mu \mathrm{l}$ samples was injected into an Inetsil ODS-3C18 column $(4.6 \mathrm{~mm} \times 250 \mathrm{~mm}$, $5 \mu \mathrm{m}$; Hichrom Limited, Berks, U.K.). The mobile phases were $1 \%$ acetic acid (mobile phase $\mathrm{A}$ ) and acetonitrile (mobile phase $B$ ) at a flow rate of $0.8 \mathrm{ml} / \mathrm{min}$. The bioactive constituents of the extract were isolated using gradient elution at $38^{\circ} \mathrm{C}$ and UV-diode array detector was used in detecting the eluted bioactive compounds in the flavonoids. The bioactive compounds were detected at $370 \mathrm{~nm}$.

\section{Data analysis}

The data were analysed using analysis of variance (ANOVA), and means were separated by Least Significant Difference (LSD) post hoc test at significant level $p<0.05$ using (SAS 9.4, Cary, NC, USA, 2009). Correlation analysis was carried out to indicate the strength of relationship among the parameters when the first-order interaction was found to be significant.

\section{Conclusion}

Considering the high medicinal value of $G$. procumbens for medicinal purposes, the optimization of the management strategies to enhance the content of phytomedicines are required. Different shade levels of $0 \%$ (full sunlight), 30\%, $50 \%$ and $70 \%$ with different nitrogen fertilizer rates of 0 (no nitrogen application), 100,200 and $300 \mathrm{~kg} \mathrm{~N} \mathrm{ha}{ }^{-1}$ significantly affected the TPC, TFC, antioxidant activities and flavonoid acids. The high light intensity ( $0 \%$ shade) and no nitrogen application ( $0 \mathrm{~kg} \mathrm{~N} \mathrm{ha}^{-1}$ ) stimulated the level of secondary metabolites (TPC and TFC) and antioxidant activity (DPPH and FRAP) of the G. procumbens. The low light intensity ( $70 \%$ shade) and high nitrogen application (300 kg N ha ${ }^{-1}$ ) accompanied by reducing the phytochemical content and antioxidant activity. This implies the ability of $G$. procumbens to produce a higher value of secondary metabolites under different stress conditions.

\section{References}

Barickman TC, Kopsell DA (2016) Nitrogen form and ratio impact Swiss chard (Beta vulgaris subsp. cicla) shoot tissue carotenoid and chlorophyll concentrations. Sci Hortic. 204: 99-105.

Bessada SMF, Barreira JCM, Barros L, Ferreira ICFR, Oliveira MBPP (2016) Phenolic profile and antioxidant activity of Coleostephus myconis (L.) Rchb. f.: An underexploited and highly disseminated species. Ind Crops Prod. 89: 45-51.
Bussotti F (2008) Functional leaf traits, plant communities and acclimation processes in relation to oxidative stress in trees: A critical overview, Global Change Biology. 14(11): 2727-2739.

Butsat S, Weerapreeyakul N, Siriamornpun S (2009) Changes in phenolic acids and antioxidant activity in Thai rice husk at five growth stages during grain development. J Agric Food Chem. 57(11): 4566-4571.

Cai ZQ, Wang WH, Yang J, Cai CT (2009) Growth, photosynthesis and root reserpine concentrations of two Rauvolfia species in response to a light gradient. Ind Crops Prod. 30(2): 220-226.

Can Z, Baltaş N, Keskin S, Yıldız O, Kolaylı S (2017) Properties of antioxidant and anti-inflammatory activity and phenolic profiles of Şevketi Bostan (Cnicus benedictus L.) cultivated in Aegean Region from Turkey. Turkish J Agri Food Sci Technol. 5(4): 308-314.

Chrysargyris A, Panayiotou C, Tzortzakis N (2016) Nitrogen and phosphorus levels affected plant growth, essential oil composition and antioxidant status of lavender plant (Lavandula angustifolia Mill.). Ind Crops Prod. 83: 577586.

Cronin G, Lodge DM (2003) Effects of light and nutrient availability on the growth, allocation, carbon/nitrogen balance, phenolic chemistry, and resistance to herbivory of two freshwater macrophytes. Oecologia. 137(1): 32-41.

El Gendy AG, El Gohary AE, Omer EA, Hendawy SF, Hussein MS, Petrova V, Stancheva I (2015) Effect of nitrogen and potassium fertilizer on herbage and oil yield of chervil plant (Anthriscus cerefolium L.). Ind Crops Prod. 69: 167174.

Ferreira ICFR, Baptista P, Vilas-Boas M, Barros L (2007) Freeradical scavenging capacity and reducing power of wild edible mushrooms from northeast Portugal: Individual cap and stipe activity. Food Chem. 100(4): 1511-1516.

Fine PV, Miller ZJ, Mesones I, Irazuzta S, Appel HM, Stevens $\mathrm{MHH}$, Saaksjarvi I, Schultz JC, Coley PD (2006) The growthdefense trade-off and habitat specialization by plants in Amazonian forests. Ecology. 87: S150-S162.

Ghasemzadeh A, Jaafar HZE, Rahmat A, Wahab PEM, Halim MRA (2010) Effect of different light intensities on total phenolics and flavonoids synthesis and anti-oxidant activities in young ginger varieties (Zingiber officinale Roscoe). Int J Mol Sci. 11(10): 3885-3897.

Gu XD, Sun MY, Zhang, L, Fu HW, Cui L, Chen RZ, Zhang DW, Tian JK (2010) UV-B induced changes in the secondary metabolites of Morus alba L. leaves. Molecules. 15(5): 2980-2993.

Hemm MR, Rider SD, Ogas J, Murry DJ, Chapple C (2004) Light induces phenylpropanoid metabolism in Arabidopsis roots. The Plant J. 38(5): 765-778.

Ibrahim M, Jaafar H, Karimi E, Ghasemzadeh A (2013) Impact of organic and inorganic fertilizers application on the phytochemical and antioxidant activity of Kacip Fatimah (Labisia pumila Benth). Molecules. 18(9): 10973-10988.

Ibrahim MH, Jaafar HZE, Rahmat A, Rahman ZA (2011) Effects of nitrogen fertilization on synthesis of primary and secondary metabolites in three varieties of Kacip Fatimah (Labisia pumila Blume ) Int J Mol Sci 12(8): 5238-5254.

Ibrahim MH, Jaafar HZE (2012) Primary, secondary metabolites, $\mathrm{H} 2 \mathrm{O} 2$, malondialdehyde and photosynthetic responses of Orthosiphon stimaneus Benth. to different irradiance levels. Molecules. 17(2): 1159-1176. 
Jiratchariyakul W, Jarikasem S, Siritantikorn S, Somanabandhu A, Frahm AW (2000) Antiherpes simplex viral compounds from Gynura procumbens Merr, Mahidol University Annual Research, Salaya, Thailand.

Kaewseejan N, Siriamornpun S (2015) Bioactive components and properties of ethanolic extract and its fractions from Gynura procumbens leaves. Ind Crops Prod. 74: 271-278.

Keng CL, Yee LS, Pin PL (2009) Micropropagation of Gynura procumbens (Lour.) Merr. An important medicinal plant. J Med Plant Res. 3(3): 105-111.

Kim J, Lee CW, Kim E K, Lee SJ, Park NH, Kim HS, Kim HK, Char K, Jang Y P, Kim J W (2011) Inhibition effect of Gynura procumbens extract on UV-B-induced matrixmetalloproteinase expression in human dermal fibroblasts, J Ethnopharmacol. 137(1): 427-433.

Kováčik J, Klejdus B (2014) Induction of phenolic metabolites and physiological changes in chamomile plants in relation to nitrogen nutrition, Food Chem. 142: 334-341.

Liu C, Guo C, Wang Y, Ouyang F (2002) Effect of light irradiation on hairy root growth and artemisinin biosynthesis of Artemisia annua L. Process Biochem. 38(4): 581-585.

Macheix JJ, Fleuriet A, Billot J (1990) Changes and metabolism of phenolic compounds in fruits, Fruit Phenolics. CRC Press Boca Raton. FL, pp. 149-221

Mou KM, Dash PR (2016) A Comprehensive Review on Gynura procumbens Leaves, Int J Pharmacogn. 3(4): 167174.

Nasir NNNM, Khandaker MM, Mat N (2015) Bioactive compound and therapeutic value of the some Malaysia medicinal plants: A review. J Agro. 14(4): 319.

Nasiri A (2016) Effect of light intensity and agronomical practices on growth, yield and quality of Sabah snake grass (Clinacanthus nutans (Burm.f.) Lindau). Universiti Putra Malaysia, Serdang, Malaysia.

Oskoee M, AghaAlikhani M, Sefidkon F, Mokhtassi-Bidgoli A, Ayyari M (2018) Blessed thistle agronomic and phytochemical response to nitrogen and plant density. Ind Crops Prod. 122: 566-573.

Perry LM, Metzger J (1980) Medicinal plant of east and South- east Asia, MIT Press, 44(92): 133.
Podsędek A (2007) Natural antioxidants and antioxidant capacity of Brassica vegetables: A review. LWT-Food Sci Technol. 40(1): 1-11.

Rahman A, Al Asad MS (2013) Chemical and biological investigations of the leaves of Gynura procumbens. Int J Biosci. 3(4): 36-43.

Rahmat A, Jaafar HZE, Haris NBM (2008) Accumulation and partitioning of total phenols in two varieties of Labisia pumila Benth. under manipulation of greenhouse irradiance, in International Workshop on Greenhouse Environmental Control and Crop Production in Semi-Arid Regions 797, pp. 387-392.

Robredo A, Pérez-López U, Miranda-Apodaca J, Lacuesta M, Mena-Petite A, Muñoz-Rueda A (2011) Elevated CO2 reduces the drought effect on nitrogen metabolism in barley plants during drought and subsequent recovery. Environm Experim Bot. 71(3): 399-408.

Sukadeetad K, Nakbanpote W, Heinrich M, Nuengchamnong $N$ (2018) Effect of drying methods and solvent extraction on the phenolic compounds of Gynura pseudochina (L.) DC. leaf extracts and their anti-psoriatic property. Ind Crops Prod. 120: 34-46.

Tan HL, Chan KG, Pusparajah P, Lee LH, Goh BH (2016) Gynura procumbens: An overview of the biological activities. Front Pharmacol.7: 52.

Thakur M, Bhattacharya S, Khosla PK, Puri S (2018) Improving production of plant secondary metabolites through biotic and abiotic elicitation. J Appl Res Med Aroma. 12: 1-12.

Wong SP, Leong LP, Koh JHW (2006) Antioxidant activities of aqueous extracts of selected plants. Food Chem. 99(4): 775-783.

Zavala JA, Ravetta DA (2001) Allocation of photoassimilates to biomass, resin and carbohydrates in Grindelia chiloensis as affected by light intensity. Field Crops Res. 69(2): 143149.

Zhao YH, Jia X, Wang WK, Liu T, Huang SP, Yang MY (2016) Growth under elevated air temperature alters secondary metabolites in Robinia pseudoacacia L. seedlings in Cd-and Pb-contaminated soils. SciTotal Environ. 565: 586-594 